\title{
Short And Mid Term Results Of Transcatheter Aortic Valve Implantation: A Single-Center Experience
}

\section{Transkateter Aort Kapak Replasmanı Kısa ve Orta Dönem Sonuçları: Tek Merkez Deneyimi}

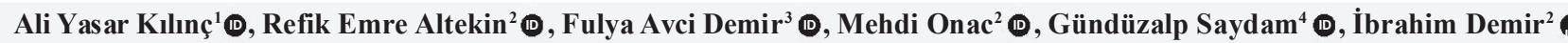 \\ ${ }^{1}$ Cardiology Department, Arnavutköy State Hospital, Istanbul, Turkey \\ ${ }^{2}$ Cardiology Department, Akdeniz University Medical Faculty Hospital, Antalya, Turkey \\ ${ }^{3}$ Cardiology Department, Anadolu Hospital, Antalya, Turkey \\ ${ }^{4}$ Cardiology Department, Cihanbeyli State Hospital, Konya, Turkey \\ Cite as: Kılınç AY, Altekin RE, Avci Demir F, Onac M, Saydam G, Demir İ. Short and mid term results of transcatheter aortic valve implantation: A single-center experience. Kocaeli \\ Med J 2021;10(2):131-139.
}

\section{Abstract}

INTRODUCTION: Patients with severe aortic stenosis and symptomatic should be treated surgically. Because of advanced age and comorbidities, $30 \%$ of patients cannot be treated. For this purpose transcatheter aortic valve replacement (TAVR) procedure has been developed. The purpose of our study is to analyze real life results of patients who underwent TAVR.

METHODS: 136 patients were analyzed retrospectively. Primary endpoint was perioperative mortality (POM), secondary endpoints were major adverse cardiovascular and cerebrovascular events (MACCE), developed during the 6-month post-procedure period and permanent pacemaker (PPM) requirement in postoperative period.

RESULTS: In patients, developed POM; PPM, transfusion and intubation requirements were higher, postoperative hemoglobin was lower, postoperative BUN, leukocyte and 48th hour creatinine were higher. PPM requirement was higher in women and patients with left bundle branch block on ECG after procedure. In patients who developed MACCE, presence of chronic obstructive pulmonary disease, intubation and transfusion requirement, preoperative CRP and postoperative CRP and leukocyte were higher. In multivariate regression analyzes, independent risk factors of POM were transfusion and PPM requirement, MACCE risk factors were intubation and transfusion requirement, and PPM risk factor was female gender.

DISCUSSION AND CONCLUSION: TAVR is an appropriate treatment option with low mortality risk in patients who cannot be operated due to high surgical risk.

Keywords: aortic stenosis, pacemaker, TAVI, TAVR, transfemoral access

Öz

GIRIŞ ve AMAÇ: Ciddi aort darlığı olan semptomatik hastalar cerrahi olarak tedavi edilmelidirler. İleri yaş ve komorbiditeler sebebi ile hastaların \%30'u tedavi edilememektedir. Bu amaçla transkateter aort kapak replasmanı (TAVR) geliştirilmiştir. Çalışmamızın amacı TAVR yapılan hastaların gerçek yaşam sonuçlarını yayınlamaktır.

YÖNTEM ve GEREÇLER: TAVR işlemi yapılan 136 hasta retrospektif incelenmiştir. Primer sonlanım noktası perioperatif mortalite (POM), sekonder sonlanımlar postoperatif 6 ay içerisinde gelişen major adverse serebrovasküler ve kardiyovasküler olaylar (MASKO) ve postoperatif kalıcı kalp pili (KKP) ihtiyacı olarak belirlenmiştir.

BULGULAR: POM gelişen hastalarda KKP, entübasyon ve kan transfüzyonu daha fazla, postoperatif hemoglobin daha düşük, postoperatif BUN, lökosit ve 48. saat kreatinin daha yüksek bulunmuştur. KKP ihtiyacı kadınlarda ve işlem sonrasında sol dal bloğu gelişen hastalarda daha fazla olmuştur. MASKO gelişen hastalarda kronik obstrüktif akciğer hastalığ 1 , entübasyon ve transfüzyon ihtiyacı daha fazla, preoperatif CRP ile postoperatif CRP ve lökosit daha yüksek bulunmuştur. POM' nin bağımsız risk faktörleri işlem sonrasında transfüzyon ve KKP ihtiyacı gelişmesi, MASKO risk faktörleri entübasyon ve transfüzyon ihtiyacı olması, KKP için risk faktörü kadın cinsiyet olmuştur.

TARTIŞMA ve SONUÇ: Transkateter aort kapak replasmanı yüksek cerrahi risk nedeni ile operasyon yapılamayan hastalarda düşük mortalite oranı ile uygun bir tedavi seçeneğidir.
Geliș tarihi / Received:

19.10.2020

Kabul tarihi / Accepted: 04.08.2021

Sorumlu Yazar/Corresponding Author: Ali Yasar Kılınç Cardiology Department, Arnavutköy State Hospital, Istanbul, Turkey

aliyasar_kilinc@hotmail.com ORCID: 0000-0003-1635-1430

R. E. Altekin 0000-0002-6438-810X F. Avci Demir 0000-0003-0608-595X

M. Onac 0000-0003-4549-3470

G. Saydam 0000-0001-6990-0793

İ. Demir 0000-0002-5092-3167

Anahtar Kelimeler: aort darlığı, kalp pili, TAVİ, TAVR, transfemoral yaklaşım 


\section{INTRODUCTION}

Aortic stenosis (AS) is a chronic, progressive disease that causes obstruction of the left ventricular outflow tract. Generally, symptoms develop after a long latent period and mortality increases rapidly after symptoms appear. The most common acquired cause is degenerative calcific AS (1). Severe AS occurs more frequently over 75 years of age and is more common in men than women (2).

Patients with severe AS and symptomatic should be treated early. Classic treatment of severe AS is surgical aortic valve replasement(SAVR) (3). Advanced age and comorbidities increase the risk of surgical mortality and morbidity. Therefore, approximately $30 \%$ of patients with severe AS cannot be treated surgically $(4,5)$. Therefore, there is a need for less invasive aortic valve intervention for patients with high surgical risk and who cannot be operated. For this purpose, transcatheter aortic valve replacement (TAVR) procedure is a reliable treatment method in such patients. After the first clinical practice in France in 2002, TAVR has become widely used all over the world (6). In randomized controlled studies, procedural, clinical and prognostic results of TAVR were evaluated in detail in various patient groups. Although these studies demonstrate the efficacy and reliability of the TAVR method, evaluation and sharing of clinical results obtained in real life data is important to guide our daily practice (7). TAVR is being implemented in our country since 2009 and in our center since 2014.

In our study, we investigated the in-hospital and early clinical real world results of TAVR patients and demographic, clinical and procedural factors of patients that may be associated with these results.

\section{MATERIALS AND METHODS}

In our non-randomized observational, retrospective study, 136 patients who were admitted to our center due to symptomatic severe aortic stenosis between January 2014 and December 2018 and were found not to be suitable for SAVR operation after heart team evaluation were included. Clinical events within the hospital and that developed in the 6-month follow-up after discharge were recorded. In-hospital events were obtained from the digital database of our hospital and clinical events during follow-up were obtained from outpatient clinic examines and phone calls. Our study was approved by local ethics committee and informed consent forms were obtained from patients before they were included the study. Our study complies with the Declaration of Helsinki Principles.

Primary endpoint was perioperative mortality (POM) and secondary endpoints were major adverse cardiovascular and cerebrovascular events (MACCE), occurred during the 6-month period after the procedure and permanent pacemakers (PPM) requirement in postoperative period. Perioperative mortality was defined as death within the first 30 days after procedure or before hospital discharge in hospitalizations lasting more than 30 days. MACCE is defined as myocardial infarction and/ or stroke, hospitalization due to decompensated heart failure, hemorrhage and all-cause mortality occurring within 6 months after the procedure. Definitions of the endpoints were determined taking into account the Valve Academic Research Consortium-2 (VARC-2) consensus report prepared by VARC and published in the European Heart Journal in 2012 (8).

Preoperative demographic data, laboratory parameters, electrocardiography(ECG) , transthoracic echocardiography (TTE), Society of Thoracic Surgery (STS) and Euroscore-2 risk scores, comorbidities, symptoms, implanted valve type, predilatation and postdilatation procedures, duration of stay in coronary intensive care unit (CICU), total hospitalization times, need for blood transfusion, postoperative ECG, TTE, laboratory data and procedure-related complications were analyzed. TTEs of all patients were performed before and after procedure in our echocardiography laboratory. Ejection fractions (EF) were calculated using biplane Simpson Method and aortic valve areas were calculated by continuity equation. Based on these data, predictive factors of POM, MACCE and PPM implantation were analyzed.

Descriptive statistics are presented with percentage, mean, standard deviation, minimum and maximum values. Fisher's Exact Test or Pearson chi-square test was used to analyze the relationships between categorical variables. The normality hypothesis of numerical variables was checked by the ShapiroWilk Test, histograms and q-q plots. Independent Samples t Test was used for the normal distribution of the two groups and MannWhitney U Test was used for the cases where it was not normally distributed. $P$ values less than 0.05 were considered statistically significant. Multivariate logistic regression analysis was used to determine independent risk factors and $95 \%$ confidence interval and $p$ value less than 0.05 were considered statistically significant. The number of variables included in the analysis was $10 \%$ of the number of patients. The independent variables were selected from the prominent values in the univariate analysis (those with $\mathrm{p}<0.2$ ). SPSS (Statistical Package for the Social Sciences) 23.0 package program was used for analysis.

\section{RESULTS}

TAVR was performed by transfemoral approach to all patients. Types of valves used in study are CoreValve ${ }^{\circledR}$ (Medtronic, Inc., Minneapolis, Minnesota, USA), Lotus TM Valve System (Boston Scientific, Boston Scientific, Natick, Minnesota, USA), Edwards-SAPIEN THV Tм (Edwards Lifesciences, Irvine, California, USA) and Portico тм (St. Jude Medical, St. Paul, Minnesota, USA). Predilatation was performed in 79 patients $(58 \%)$ and postdilatation was performed in 55 patients $(40.4 \%)$. All predilatation and postdilatation procedures were performed with temporary pacemaker and overdrive pacing. Atrioventricular complete block (AVTB) or asystole was the most common complication during the operation and occurred in $24(18.5 \%)$ patients. PPM was implanted in these patients after 
the procedure. The demographic characteristics of the patients, types of valves and procedural complications are given in Table 1.

All patients were followed-up in CICU after the procedure. Average length of stay in CICUwas $5.57 \pm 4.4$ days and average length of hospital stay was $10.98 \pm 6.18$ days. The least hospitalized patient was hospitalized for 3 days after procedure and was discharged without any complications. The longest hospital stay was 41 days and 29 days in CICU.

Perioperative mortality occurred in 12 patients (8.8\%). Preoperative and postoperative data of patients with and without POM are shown in Table-2. Patients with POM had lower postop hemoglobin levels and therefore needed more transfusions. POM was higher in patients who required PPM implantation $(p=0.001)$. In addition, the rate of intubation was higher in patients who developed POM and postoperative BUN levels and creatinine levels measured at 48 hours postoperatively were higher than those without mortality.

There was a statistically significant relationship between POM and postoperative ECG. Postoperative mortality was lower in patients with sinus rhythm without any interventricular conduction delay. Conversely, mortality rate was higher in patients with sinus rhythm and left bundle branch block(LBBB) after operation. Patients with left bundle branch block after the procedure had more need for PPM implantation (Table 3).

Post-procedural PPM was implanted to 24 patients. 18 of these patients were female and 6 were male $(p=0.031)$. PPM was implanted in $6(10.3 \%)$ of 58 patients who underwent postdilation and $18(25 \%)$ of patients without postdilatation. The need for PPM was less in patients who underwent postdilation (p: 0.029). CICU period was longer in those who were implanted PPM $(5.3 \pm 3.7)$ than those who did not implanted $(4.4 \pm 3.9)$ $(\mathrm{p}=0.006)$.

Of the 124 patients who survived after perioperative period, $34(27.4 \%)$ had MACCE. Hospitalization due to decompensated heart failure was the most common cause. Gastrointestinal bleeding occurred in three patients and but only one required $1 \mathrm{U}$ erythrocyte suspension transfusion and all patients were discharged. During the 6-month period, 8 patients who were discharged from the hospital, died (Table 4).

It was observed that frequency of chronic obstructive pulmonary disease (COPD) was higher in patients who developed MACCE within 6 months, these patients needed more transfusion after the procedure and intubated for a longer period. In addition, preoperative CRP, postoperative CRP and leukocyte values were found to be higher in patients who developed MACCE compared to other patients (Table 5).

Multivariate logistic regression analysis for POM was performed using postoperative PPM requirement, postoperative transfusion requirement, creatinine levels measured at 48th hour and postoperative leukocyte levels. After analysis, transfusion and PPM requirement were found to be independent risk factors for perioperative mortality. POM was approximately 7 -fold
Table-1: Baseline characteristics, implanted valve types and operation-related complications

\begin{tabular}{|c|c|c|}
\hline & No. & Percent(\%) \\
\hline Baseline Characteristics & 136 & 100 \\
\hline Female Gender & 81 & 59.6 \\
\hline Hypertension & 109 & 80.1 \\
\hline Diabetes Mellitus & 57 & 41.9 \\
\hline CKD & 40 & 29.5 \\
\hline On Hemodialysis & 3 & 2.2 \\
\hline COPD & 24 & 17.6 \\
\hline $\mathrm{CAD}$ (total) & 71 & 52.2 \\
\hline Previous PCI & 55 & 40.4 \\
\hline Previous CABG & 16 & 11.8 \\
\hline Permenant Pacemaker & 6 & 4.4 \\
\hline Bioprosthesis Aortic Valve & 2 & 1.4 \\
\hline Mechanical Mitral Valve & 6 & 4.4 \\
\hline Implanted Valve Types(total) & 136 & 100 \\
\hline CoreValve & 3 & 2.2 \\
\hline Lotus & 3 & 2.2 \\
\hline Edwards-SAPIEN THV & 29 & 21.3 \\
\hline Portico & 101 & 74.3 \\
\hline Operation-related Complications & 56 & 41.1 \\
\hline Atrioventricular Complete & 24 & 18.5 \\
\hline \multicolumn{3}{|l|}{ Block/Asystole $¥$} \\
\hline Acute Kidney Injury* & 11 & 8.2 \\
\hline Vascular Complications & 8 & 5.9 \\
\hline Transient Ischemic & 3 & 2.2 \\
\hline \multicolumn{3}{|l|}{ Attack/Cerebrovascular Event } \\
\hline CardiacTamponad & 3 & 2.2 \\
\hline Aortic Root Rupture & 1 & 0.7 \\
\hline Right Coronary Artery Obstruction & 1 & 0.7 \\
\hline Cardiogenic Shock & 1 & 0.7 \\
\hline Severe Aortic Failure & 1 & 0.7 \\
\hline Left Main Coronary Artery Plaque & 1 & 0.7 \\
\hline \multicolumn{3}{|l|}{ Shift } \\
\hline Valve Migration & 1 & 0.7 \\
\hline Thrombocytopenia & 1 & 0.7 \\
\hline
\end{tabular}

CAD Coronary Artery Disease, CKD Chronic Kidney Disease, COPD Chronic Obstructive Pulmonary Disease, PCI Percutaneous Coronary Intervention, CABG Coronary Artery Bypass Graft

$¥$ Six patients with pacemaker before procedure were not included.

* It was calculated by excluding 3 patients undergoing hemodialysis. 
Table-2: Data of patients with and without perioperative mortality

\begin{tabular}{|c|c|c|c|}
\hline Parameter & Without(n=124) & With(n=12) & P value \\
\hline Age(year) & $77.7 \pm 7$ & $79.5 \pm 7.7$ & 0.485 \\
\hline Female-No.(\%) & $48(\% 38.7)$ & $7(\% 58.3)$ & 0.225 \\
\hline Hypertension-No. (\%) & $100(\% 80.6)$ & $9(\% 75)$ & 0.705 \\
\hline DM-No.(\%) & $50(\% 40.3)$ & $7(\% 58.3)$ & 0.227 \\
\hline COPD-No.(\%) & $22(\% 17.7)$ & $2(\% 16.7)$ & 1 \\
\hline Euroscore-2 Risc Score & $30 \pm 17.7$ & $33 \pm 23.3$ & 0.854 \\
\hline STS Morbidity And Mortality Score & $32.8 \pm 14.4$ & $37.1 \pm 15.1$ & 0.197 \\
\hline BUN (mg/dl) & $26.1 \pm 14.1$ & $31 \pm 19.7$ & 0.179 \\
\hline Creatinine (mg/dl) & $1.1 \pm 0.75$ & $1 \pm 0.28$ & 0.603 \\
\hline GFR $(60 \mathrm{ml} / \mathrm{dk} / 1.73 \mathrm{~m} 2)$. & $67 \pm 24.7$ & $68 \pm 19.9$ & 0.884 \\
\hline HbA1c (\%) & $6.1 \pm 0.9$ & $6.8 \pm 1.4$ & 0.163 \\
\hline $\mathrm{LDL}(\mathrm{mg} / \mathrm{dl})$ & $101.1 \pm 34.4$ & $91.4 \pm 24.8$ & 0.385 \\
\hline $\operatorname{HDL}(\mathrm{mg} / \mathrm{dl})$ & $41.2 \pm 13.3$ & $36.6 \pm 10.6$ & 0.214 \\
\hline Triglycerides $(\mathrm{mg} / \mathrm{dl})$ & $120.9 \pm 53.8$ & $123.9 \pm 55.2$ & 0.944 \\
\hline Hemoglobin (g/dl) & $11.1 \pm 1.5$ & $10.5 \pm 1.8$ & 0.272 \\
\hline Leukocyte $\left(10^{9} / \mathrm{L}\right)$ & $7.3 \pm 2.5$ & $7.6 \pm 2$ & 0.698 \\
\hline Neutrophil $\left(10^{9} / \mathrm{L}\right)$ & $4.8 \pm 2.5$ & $5.3 \pm 1.6$ & 0.269 \\
\hline Lymphocytes $\left(10^{9} / \mathrm{L}\right)$ & $1.4 \pm 0.6$ & $1.3 \pm 0.57$ & 0.704 \\
\hline N/L Ratio & $4.9 \pm 6.3$ & $5.3 \pm 3.9$ & 0.233 \\
\hline Left Atrial Size (mm) & $45.5 \pm 6.7$ & $44.9 \pm 9.8$ & 0.770 \\
\hline Left Ventricular End-Diastolic Diameter (mm) & $47 \pm 6.2$ & $45.3 \pm 5.4$ & 0.364 \\
\hline Left Ventricular End-Systolic Diameter (mm) & $32.7 \pm 7.3$ & $31.9 \pm 7$ & 0.649 \\
\hline Posterior Wall(mm) & $12.8 \pm 2.1$ & $12.3 \pm 2.5$ & 0.237 \\
\hline Interventricular Septum (mm) & $13 \pm 2.4$ & $13 \pm 2.8$ & 0.735 \\
\hline Ejection Fraction (\%) & $54.5 \pm 10.4$ & $54.1 \pm 9.5$ & 0.761 \\
\hline Aortic Velocity $(\mathrm{m} / \mathrm{sec})$ & $4.7 \pm 0.69$ & $4.7 \pm 0.68$ & 0.950 \\
\hline Aort Peak Gradient (mm Hg) & $91 \pm 27.3$ & $91.4 \pm 27.6$ & 0.915 \\
\hline Aort Mean Gradient (mm Hg) & $54.4 \pm 18.8$ & $59.9 \pm 18.8$ & 0.498 \\
\hline Aort Valve Area $(\mathrm{cm} 2)$ & $0.6 \pm 0.19$ & $0.58 \pm 0.14$ & 0.653 \\
\hline sPAB (mm Hg) & $49 \pm 12.4$ & $55 \pm 17.7$ & 0.418 \\
\hline Predilatation -No.(\%) & $69(\% 55.6)$ & $8(\% 72.7)$ & 0.352 \\
\hline Postdilatation-No.(\%) & $57(\% 46)$ & $3(\% 25)$ & 0.164 \\
\hline Postoperative Hemoglobin (g/dl) & $10.6 \pm 1.5$ & $9.2 \pm 1.3$ & 0.03 \\
\hline Postoperative Creatinine (mg/dl) & $1.1 \pm 0.75$ & $1.1 \pm 0.4$ & 0.251 \\
\hline Postoperative 48th Hour Creatinine (mg/dl) & $1.1 \pm 0.78$ & $1.6 \pm 0.6$ & 0.004 \\
\hline Postoperative BUN(mg/dl) & $24.6 \pm 12.4$ & $35 \pm 21$ & 0.028 \\
\hline Postoperative CRP(mg/dl) & $5.3 \pm 5.5$ & $6.9 \pm 6$ & 0.282 \\
\hline Postoperative Leukocyte $\left(10^{9} / \mathrm{L}\right)$ & $9.7 \pm 3.9$ & $12.4 \pm 4.3$ & 0.031 \\
\hline Postoperative Aortic Velocity (m/sec) & $2 \pm 0.35$ & $1.8 \pm 0.3$ & 0.193 \\
\hline Intubation-No.(\%) & $8(\% 6.5)$ & $10(\% 83.3)$ & $<0.001$ \\
\hline Postoperative Transfusion Need-No.(\%) & $45(\% 36.3)$ & $9(\% 75)$ & 0.013 \\
\hline Postoperative PPM Need-No.(\%)¥ & $16(\% 12.9)$ & $8(\% 66.7)$ & 0.001 \\
\hline Total Length of HospitalStay(day) & $10.5 \pm 5.5$ & $12.3 \pm 6.8$ & 0.209 \\
\hline Length of Stay in CICU(day) & $4.4 \pm 3.7$ & $6.6 \pm 4.7$ & 0.09 \\
\hline
\end{tabular}

BUN Blood Urea Nitrogen, CICU Coronary Intensive Care Unit, COPD Chronic Obstructive Pulmonary Disease, CRP C- Reactive Protein, DM Diabetes Mellitus, GFR Glomerular Filtration Rate, HbAlc Glycolized Hemoglobin, HDL High Density Lipoprotein, LDL Low Density Lipoprotein, PPM Permenant Pacemaker, Spab Systolic Pulmonary Artery Pressure, STS Society of Thoracic Surgery Score

\pm means Standard deviation, ¥; Six patients with pacemaker before procedure were not included.

Bold data indicate statistical significance. 
Table-3: Relationship between postoperative ECG and perioperative mortality and pacemaker requirement

\begin{tabular}{|c|c|c|c|}
\hline PerioperativeMortality & Without(119(\%100)) & With(11(\%100)) & Total $(130(\% 100))$ \\
\hline SR & $60(\% 50.4)$ & $2(\% 18.2)$ & $62(\% 47.7)$ \\
\hline $\mathrm{AF}$ & $29(\% 24.4)$ & $1(\% 9.1)$ & $30(\% 23)$ \\
\hline SR+LBBB & $12(\% 10.1)$ & $6(\% 54.6)$ & $18(\% 13.8)$ \\
\hline $\mathrm{SR}+\mathrm{RBBB}$ & $13(\% 10.9)$ & $1(\% 9.1)$ & $14(\% 10.7)$ \\
\hline $\mathrm{AF}+\mathrm{LBBB}$ & $2(\% 1.7)$ & $1(\% 9.1)$ & $3(\% 2.3)$ \\
\hline $\mathrm{AF}+\mathrm{RBBB}$ & $3(\% 2.3)$ & 0 & $3(\% 2.3)$ \\
\hline PPM Requirement & No(106(\%100)) & Requirement $(24(\% 100))$ & Total $(130(\% 100))$ \\
\hline SR & $57(\% 53.7)$ & $3(\% 12.5)$ & $60(\% 46.1)$ \\
\hline $\mathrm{AF}$ & $29(\% 27.3)$ & $1(\% 4.1)$ & $30(\% 23.2)$ \\
\hline SR+LBBB & $3(\% 2.8)$ & $12(\% 50)$ & $15(\% 11.5)$ \\
\hline $\mathrm{SR}+\mathrm{RBBB}$ & $13(\% 12.2)$ & $5(\% 20.8)$ & $18(\% 13.8)$ \\
\hline $\mathrm{AF}+\mathrm{LBBB}$ & $0(\% 0)$ & $2(\% 8.3)$ & $2(\% 1.5)$ \\
\hline $\mathrm{AF}+\mathrm{RBBB}$ & $4(\% 3.8)$ & $1(\% 4.1)$ & $5(\% 3.8)$ \\
\hline
\end{tabular}

AF Atrial Fibrillation, LBBB Left Bundle Branch Block, PPM Permenant Pacemaker, RBBB Right Bundle Branch Block, SR Sinus Rhythm Fischer 's Exact test was used for the evaluation of binary variables and p value was found to be 0.04.

Bold data indicate statistical significance.

Table-4: Major Adverse Cardiovascular and Cerebrovascular Events (MACCE) occurring within 6 months post-operatively

\begin{tabular}{lc}
\hline MACCE & No.(\%) \\
\hline Hospitalization For Decompensed Heart Failure & $17(13.7)$ \\
Gastrointestinal Bleeding & $3(2.4)$ \\
Myocardial Infarction & $1(0.8)$ \\
Need For Pacemaker in Subsequent Periods & $2(1.6)$ \\
Vascular Complication & $2(1.6)$ \\
Stroke & $1(0.8)$ \\
All-Caused Mortality & $8(6.4)$ \\
Total & $34(27.4)$ \\
\hline
\end{tabular}

Table-5: Data showing statistically significant differences between MACCE and non-MACCE groups

\begin{tabular}{llll}
\hline Parameter & Non-MACCE & MACCE & p value \\
\hline Presence of COPD-No.(\%) & $11(\% 12.1)$ & $11(\% 32.4)$ & 0.008 \\
Transfusion Requirement-No.(\%) & $27(\% 29.7)$ & $19(\% 55.9)$ & 0.007 \\
Intubation-No.(\%) & $2(\% 2.2)$ & $7(\% 20.6)$ & 0.002 \\
Preoperative CRP(mg/dl) & $2.57 \pm 6.43$ & $3.53 \pm 4.61$ & $<0.001$ \\
Postoperative CRP(mg/dl) & $4,7 \pm 5$ & $7 \pm 6.6$ & 0.024 \\
Postoperative Leukocyte (10\%/L) & $9,4 \pm 4$ & $10.8 \pm 3.5$ & 0.017 \\
\hline
\end{tabular}

COPD Chronic Obstructive Pulmonary Disease, CRP C-Reactive Protein, No: Number of

\pm means Standard deviation 
higher in transfused patients and approximately 22-fold higher in those requiring PPM implantation. Regression analysis was performed using postdilatation amount and female gender ratio for patients who required PPM implantation after the procedure. It was seen that female gender increased requirement of PPM after the procedure 3.5 times. For MACCE, regression analysis was performed using transfusion, amount of intubation, presence of COPD and amount of postoperative CRP. Need for transfusion and intubation were independent risk factors for MACCE development (Table 6).

\section{DISCUSSION}

All symptomatic AS patients should be treated early. Hemodynamic and clinical improvement is known in AS patients treated with SAVR (3). At least $30 \%$ of patients with severe AS cannot undergo surgery because of comorbidities, advanced age, and LV dysfunction (4,5). For this purpose, TAVR procedure, which has been implemented in our country as well as in the world, has been developed. TAVR is a minimally invasive procedure that does not require general anesthesia and cardiopulmonary bypass. In the procedure, bioprosthesis valve is inserted into a catheter and implanted into native aortic valve. In previous observational studies, 1-year all-cause mortality rate in patients who underwent TAVR was around $25 \%$ $(9,10)$. In 2010, The Placement of Aortic Transcatheter Valves (PARTNER-1) study examined 179 patients who underwent TAVR and a significant decrease was observed in cause-related deaths (11). Considering other studies in the literature, TAVR has become the treatment modality used in severe AS patients with high surgical risk.

Of the 136 patients who underwent TAVR in our center, 12 died in the perioperative period and 8 died in the next 6 months. At the end of the 6-month follow-up period, 116 patients (85.3\%) survived and any event did not develop in 90 patients $(66.1 \%)$. Mortality, complications and survival rates of TAVR procedure performed in our center were similar with previous studies (11). Independent risk factors for POM include post-procedure blood transfusion and PPM requirement; for MACCE, transfusion requirement and intubation are independent risk factors. Female patients had more post-procedure PPM requirements than men.

The primary outcome of the study was POM, occurred in 12 patients (8.8\%). At 2017, 147 patients who underwent TAVR in Ireland were analyzed and the POM rate was 9.5\% (12). Perioperative mortality rate was reported as $9.7 \%$ by Çiftçi et. al at 2014 (13) and was similar with our center. In our study, we

Table-6:Multivariate logistic regression analysis for end-points

\begin{tabular}{cccccc}
\hline & & & & \multicolumn{2}{c}{$95 \%$ C.I.for Odds Ratio } \\
B & Wald & Sig & OddsRatio & Lower & Upper
\end{tabular}

\section{Factors Associated with Perioperative Mortality}

$\begin{array}{lcccccr}\text { Postoperative Leukocyte } & 0.106 & 1.487 & 0.223 & 1.112 & 0.938 & 1.319 \\ \text { Transfusion Requirement } & 1.934 & 5.187 & 0.023 & 6.919 & 1.31 & 36.55 \\ \text { Postoperative PPM Need } & 3.076 & 13.402 & <0.001 & 21.674 & 4.175 & 112.501 \\ \text { Postoperative 48th Hour Creatinine } & 0.448 & 1.728 & 0.189 & 1.566 & 0.802 & 3.054\end{array}$

\begin{tabular}{lcccccc}
\hline Factors Associated with Permenant Pacemaker Requirement & & & \\
\hline Postdilatation & 0.602 & 1.651 & 0.199 & 1.86 & 0.722 & 4.796 \\
Female & 1.239 & 5.308 & 0.021 & 3.452 & 1.203 & 9.905 \\
\hline
\end{tabular}

Factors Associated with Major Adverce Cardiovascular and Cerebrovascular Events

\begin{tabular}{lcccccc}
\hline COPD & -1.322 & 5.233 & 0.220 & 0.267 & 0.086 & 0.827 \\
Intubation & -2.041 & 5.536 & 0.019 & 0.130 & 0.024 & 0.711 \\
Transfusion Requirement & -1.281 & 7.073 & 0.008 & 0.278 & 0.108 & 0.714 \\
Postoperative CRP & 0.056 & 2.086 & 0.149 & 1.057 & 0.980 & 1.141 \\
\hline
\end{tabular}

COPD Chronic Obstructive Pulmonary Disease, CRP C-Reactive Protein, PPM Permenant Pacemaker 
also found that the rate of intubation was higher in patients who developed POM.

The mean values of preoperative hemoglobin levels in patients with POM were similar to those of the surviving group, but postoperative hemoglobin levels were significantly lower and transfusion requirements were higher. It was found that postoperative transfusion requirement increased perioperative mortality 7 times. In a study published at 2014, perioperative mortality was found to be higher in patients who needed blood transfusion after the procedure (14). In a study written by Konigstein et al. it was found that 1 -year mortality rates were higher in patients who were transfused, irrespective of the amount of hemoglobin decrease after the TAVR procedure (15).

In a study published by Condado et al. at 2016, 580 patients undergoing TAVR were examined. POM rate was found to be significantly higher in patients with high neutrophil to lymphocyte ratio (N / L) (16). In a study published at 2017, 238 patients who underwent TAVR were analyzed. The relationship between N / L ratio and 1-year MACCE (all-cause mortality, myocardial infarction and mortality) was examined and N/ L ratio was found to be the predictor of all-cause mortality (17). In our study, neither perioperative mortality nor MACCE development was found to be related to N/L ratio. Differently, postoperative leukocyte levels were higher in patients with perioperative mortality. In addition, preoperative and postoperative CRP levels and postoperative leukocyte levels were higher in patients who developed MACCE within 6 months.

Forty of patients who underwent TAVR had CKD and 3 were on dialysis. 11 of 133 patients $(8.2 \%)$ developed acute renal failure(ARF) except for 3 patients who underwent hemodialysis. In addition, creatinine levels measured at 48 hours after the procedure were significantly higher in patients who died in the perioperative period compared with the surviving group. BUN levels measured in postoperative period were higher in these patients. In a study published by Antonio J. Muñoz-García et al. at 2015, it was shown that development of ARF predicted shortand mid-term mortality in patients who underwent CoreValve valve implantation (18). At 2012 study published byAlassar et al. incidence of ARF was found to be $12.3 \%$ in patients undergoing TAVR. Statistical analysis showed that the development of ARF has no effect on 1-year mortality (19). In contrast, in a study published in 2015, which examined 203 patients, a significant relationship was found between ARF development and 2-year mortality after procedure and mortality rate was higher in patients with ARF (20). In our study, creatinine levels measured at 48th hour after the procedure were found to be higher in patients who developed POM but there was no difference between patients who developed MACCE and those who did not.

In our study, 6 patients (4.4\%) had PPM before procedure and 24 patients (18.5\%) required PPM after the procedure. Patients who developed PPM requirement, stay longer in CICU than patients without need. In previous studies, rate of postoperative PPM requirement varies according to type of implanted valve and there is large variation in rate of PPM requirement. In literature, rate of PPM requirement is between $6-25 \%(21,22)$. In our study, patients who developed LBBB after procedure had more need for PPM. In addition, perioperative mortality was found to be lower in patients with sinus rhythm on ECG postoperatively and without any interventricular conduction delay. The mortality rate was higher in patients with sinus rhythm who developed left bundle branch block after the procedure.

In the study titled 'Acute and 30-Day Results in WomenAfter TAVR' was published in 2016, the need for PPM was $11.6 \%$ in women who underwent TAVR (23). In a study published by Fraccaro et al. in 2013, it was found that PPM requirement was higher in women undergoing TAVR (24). Similarly, in our study, post-procedure PPM requirement was found to be significantly higher in women than men. Based on this result, we think that it is appropriate to keep these patients under close observation for a longer period after the procedure.

Transfemoral approach was applied to all patients. Vascular complications developed in 8 patients (5.9\%) and were successfully repaired by surgical intervention. In previously published studies, the rate of vascular complications varies greatly and the incidence varies between $4-20 \%$ in general $(25,26)$. We think that our vascular complication rate is acceptable considering previous studies. In a published metaanalysis, it was reported that the risk of aortic root rupture is $1.1 \%$ in patients undergoing TAVR procedure (27). It was also seen in our center with a similar frequency. In addition, a previously published study reported that the rate of coronary occlusion was less than $1 \%(28)$. In our center, this situation occurred in one patient. One patient had plaque shift from aorta to LMCA and was treated by stenting. Later, late stent thrombosis occurred and the patient was given emergency $\mathrm{CABG}$, but patient died intraoperatively.

In a study published at 2017 and examining 188 patients undergoing TAVR, the Euroscore-2 risk score was found to be strong in predicting long-term mortality, but it was shown that the risk score was poor in predicting short-term mortality (29). In a different study published at 2015 and examining 458 TAVR patients, all risk scoring systems were shown to be poor in predicting short- and long-term mortality (30). In our study, it was also concluded that the Euroscore-2 risk score and STS morbidity and mortality risk score did not predict POM and MACCE. In addition, our study is based on real life data and includes a more heterogeneous group of patients. In addition, besides the classical risk scores, individual risk parameters such as fragility are important factors that determine clinical outcomes.

The main limitation of our study is that it is a non-randomized observational study. In our study, classical preoperative risk scores were used, but the effects of individual comorbidities and fragility indices of the patients on the study results could not be excluded. Results of 4 different valve types were evaluated together. However, due to the differences in the numerical 
distribution of the valves, results have not been evaluated according to the types of valves.

\section{CONCLUSIONS}

According to our results from real life data, TAVR procedure seems to be an appropriate treatment option with relatively low mortality risk in patients who cannot undergo SAVR due to high surgical risk. The efficacy and reliability of TAVR method in our daily treatment practice should be supported by studies consisting of larger scale, longer follow-up time with real life data.

Ethics Committee Approval: Akdeniz University Faculty of Medicine Clinical Research Ethics Committee (21.11.2017 / 70904504/410)

Conflict of Interest: The author report no declarations of interest. Funding: No financial support was received.

Informed Consent: Written informed consent was obtained from the patients.

\section{REFERENCES}

1. Passik CS, Ackerman DM, Pluth JR. Temporal changes in the causes of aortic stenosis: A surgical pathological study of 646 cases. Mayo Clin Proc 1987; 62: 119-23. https://doi.org/10.1016/S0025-6196(12)61880-1

2. Townsend CM, Beauchamp RD, et al . Sabiston Textbook of Surgery. 18th ed. Saunders 2008; 1841-4.

3. 2017 ESC/EACTS Guidelines for the management of valvular heart disease, European Heart Journal 2017; 38: 2739-86. doi:10.1093/eurheartj/ehx391

https://doi.org/10.1093/eurheartj/ehx391

4. Bouma BJ, van den Brink RBA, van der Meulen JHP, et al. To operate or not on elderly patients with aortic stenosis: the decision and its consequences. Heart 1999; 82: 143-8. https://doi.org/10.1136/hrt.82.2.143

5. Iung B, Cachier A, Baron G, et al. Decision-making in elderly patients with severe aortic stenosis: why are so many denied surgery? Eur Heart J 2005; 26: 2714-20.

https://doi.org/10.1093/eurheartj/ehi471

6. Cribier A, Eltchaninoff $\mathrm{H}$, Bash A, et al. Percutaneous Transcatheter Implantation of an Aortic Valve Prosthesis for Calcific Aortic Stenosis. Circulation 2002; 106: 3006-8. https://doi.org/10.1161/01.CIR.0000047200.36165.B8

7. Yücel G, Paker T, Akçevin A, et al. Transcatheter aortic valve implantation: the first applications and early results in Turkey. [Article in Turkish] Turk Kardiyol Dern Ars 2010; 38: 258-63.

8. Kappetein AP, Head SJ, Genereux P, et al. Updated standardized endpoint definitions for transcatheter aortic valve implantation: the Valve Academic Research Consortium-2 consensus document, European Heart Journal 2012; 33: 2403-18. doi:10.1093/eurheartj/ehs255 https://doi.org/10.1093/eurheartj/ehs255

9. Himbert D, Descoutures F, Al-Attar N, et al. Results of transfemoral or transapical aortic valve implantation following a uniform assessment in high-risk patients with aortic stenosis. J Am Coll Cardiol 2009; 54: 303-11.

https://doi.org/10.1016/j.jacc.2009.04.032

10. Webb JG, Altwegg L, et al. Transcatheter aortic valve implantation: impact on clinical and valve-related outcomes. Circulation 2009; 119: 3009-16. https://doi.org/10.1161/CIRCULATIONAHA.108.837807

11. Leon MB, Smith CR, Mack M, et al, for the PARTNER Trial Investigators, Transcatheter Aortic-Valve Implantation for Aortic Stenosis in Patients Who Cannot Undergo Surgery. N Engl J Med 2010; 363: 1597-607.

12. BajrangeeA, Coughlan JJ, Teehan S, et al Early and mid-term outcomes after transcatheter aortic valve implantation (TAVI) in Ireland, http://dx.doi.org/10.1016/j.ijcha.2017.06.001 https://doi.org/10.1016/j.ijcha.2017.06.001

13. Çiftçi A, Kesimci E, Gümüş T, ve ark. Lokal Anestezi ve Sedasyon Altında Yapılan Transkateter Aort Kapak Cerrahisi HastalarındakiAnestezi Deneyimlerimiz, GKDA Derg 2014; 20(4): 202-8. doi:10.5222/GKDAD.2014.202 https://doi.org/10.5222/GKDAD.2014.202

14. Escárcega RO, Lipinski MJ, Magalhaes MA et al. Impact of Blood Transfusions on Short- and Long-Term Mortality in Patients Who Underwent Transcatheter Aortic Valve Implantation, DOI: https://doi.org/10.1016/j. amjcard.2014.09.046 https://doi.org/10.1016/j.amjcard.2014.09.046

15. Konigstein, Havakuk O, Arbel Y, et al. The Impact of Hemoglobin Drop, Bleeding Events and Blood Transfusion on Long Term Mortality Following Transcatheter Aortic Valve Implantation. Circulation 2015; 132: A14026

16. Condado JF, Junpaparp P, Binongo JN, et al. Neutrophillymphocyte ratio (NLR) and platelet-lymphocyte ratio (PLR) can risk stratify patients in transcatheter aortic-valve replacement (TAVR). International Journal of Cardiology 2016; 223: 444-9. https://doi.org/10.1016/j.ijcard.2016.08.260

17. Khalil C, Pham M, Sawant A, et al. Predictive Value of Neutrophil to Lymphocyte Ratio in Transcatheter Aortic Valve Replacement Patients, Journal of the American College of Cardiology 2017; 70(18), Abstract no: 223-7. https://doi.org/10.1016/j.jacc.2017.09.301

18. Muñoz-García AJ, Muñoz-García E, Jiménez-Navarro MF, et al. Clinical impact of acute kidney injury on shortand long-term outcomes after transcatheter aortic valve implantation with the CoreValve prosthesis, Journal of Cardiology 2015; 66: 46-9. https://doi.org/10.1016/j.jjcc.2014.09.009

19. Alassar A, Abdulkareem N, Valencia O, et al. Acute kidney injury following TAVI: incidence, predictive factors and prognostic effects, Innovations (Phila) 2012; 7(6): 389-93. 
https://doi.org/10.1177/155698451200700603

20. Chatani K, Abdel-Wahab M, Wübken-Kleinfeld N, et al. Acute kidney injury after transcatheter aortic valve implantation: Impact of contrast agents, predictive factors, and prognostic importance in 203 patients with long-term follow-up. https://doi.org/10.1016/j.jjcc.2015.02.007 https://doi.org/10.1016/j.jjcc.2015.02.007

21. Erkapic D, De Rosa S, Kelava A, et al. Risk for permanent pacemaker after transcatheter aortic valve implantation: A comprehensive analysis of the literature. J Cardiovasc Electrophysiol 2012; 23: 391-7.

https://doi.org/10.1111/j.1540-8167.2011.02211.x

22. Khatri PJ, Webb JG, Rodés-Cabau J, et al. Adverse effects associated with transcatheter aortic valve implantation: a meta-analysis of contemporary studies. Ann Intern Med 2013; 158: 35-46.

https://doi.org/10.7326/0003-4819-158-1-201301010-00007

23. Chieffo A, Petronio AS, Mehilli J, et al. Acute and 30-Day Outcomes in Women After TAVR. J Am Coll Cardiol Intv 2016; 9: 1589-600.

https://doi.org/10.1016/j.jcin.2016.05.015

24. Fraccaro C, Napodano M, Tarantini G. Conduction disorders in the setting of transcatheter aortic valve implantation: a clinical perspective. Catheter Cardiovasc Interv. 2013 Jun 1;81(7):1217-23.

https://doi.org/10.1002/ccd.24713

25. Tomey MI, Mehran R. Bleeding avoidance in transcatheter aortic valve replacement: a call toACTion? JACC Cardiovasc Interv 2014; 7: 152. https://doi.org/10.1016/j.jcin.2013.11.007

26. Van Mieghem NM, Tchetche D, Chieffo A, et al. Incidence, predictors, and implications of access site complications with transfemoral transcatheter aortic valve implantation. Am J Cardiol 2012; 110: 1361. https://doi.org/10.1016/j.amjcard.2012.06.042

27. Athappan G, Gajulapalli RD, Sengodan P, et al. Influence of transcatheter aortic valve replacement strategy and valve design on stroke after transcatheter aortic valve replacement: a meta-analysis and systematic review of literature. J Am Coll Cardiol 2014; 63: 2101-10.

https://doi.org/10.1016/j.jacc.2014.02.540

28. Genereux P, Head SJ, Van Mieghem NM, et al. Clinical outcomes after transcatheter aortic valve replacement using valve academic research consortium definitions: a weighted meta-analysis of 3,519 patients from 16 studies, J Am Coll Cardiol 2012; 59: 2317-26.

https://doi.org/10.1016/j.jacc.2012.02.022

29. Kai T, Wang M, Rea C, et al. Mortality Prediction Assessment with EuroSCORE II for Transcatheter Aortic Valve Implantation, DOI: https://doi.org/10.1016/j. hlc.2017.05.097

https://doi.org/10.1016/j.hlc.2017.05.097

30. Silaschi M, Conradi L, Seiffert M, et al. Predicting Risk in Transcatheter Aortic Valve Implantation: Comparative AnalysisofEuroSCOREIIandEstablishedRiskStratification Tools. Thorac Cardiovasc Surg 2015; 63(6): 472-8. https://doi.org/10.1055/s-0034-1389107 